\title{
DINAMIKA PENGATURAN TENAGA KERJA ASING DI INDONESIA
}

\author{
Riza Fauziah Djazuli \\ Pascasarjana Universitas Islam Negeri Sunan Gunung Djati Bandung, Indonesia \\ Email:fauriahriza11@gmail.com
}

Received: 15 Desember 2020; Accepted: 29 Maret 2021; Published: 31 Maret 2021

\begin{abstract}
The unemployment rate in Indonesia has soared high enough since August 2020 with a total of 9,77 million person, while data on foreign labor recorded in 2020 amounted to 98.902 person. From this data, foreign workers from China rank first, namely 35,781 people or the equivalent of $36.17 \%$. The research purposes are, firstly, to analyze the legal aspects of foreign labor in terms of national responsibility which is closely related to Article 27 verse (2) of the Constitution of 1945; secondly, to analyze the efforts to protect Indonesian employment law in terms of the national responsibility which is closely related to Article 27 verse (2) of the Constitution of 1945. This research used descriptive analytical method with normative juridical approach. Aspects of foreign employment law in terms of national responsibility are seen in the regulation of the control of foreign labor which can only be done in a worke relationship for a certain time. Even though this needs to be emphasized regarding legal protection and social welfare insurance like domestic workers. In addition, in terms of supervision of foreign workers, there should be no imbalance in rights and obligations between foreign workers and domestic workers. Efforts to protect Indonesian labor law in terms of the national responsibility can be seen in the implementation of efforts to educate and train domestic labor in order to improve competency standards that are able to compete with foreign labor.
\end{abstract}

Keywords: foreign labor; national responsibility; control.

\begin{abstract}
Abstrak
Angka pengangguran di Indonesia melonjak cukup tinggi terhitung sejak Agustus 2020 dengan jumlah 9,77 juta orang, sementara data Tenaga Kerja Asing (TKA) pada tahun 2020 tercatat berjumlah 98.902 orang. Berdasarkan data tersebut, TKA yang paling banyak di Indonesia berasal dari Negara China yaitu 35.781 orang atau setara 36,17\%. Tujuan penelitian ini adalah, pertama untuk menganalisis aspek hukum ketenagakerjaan asing ditinjau dari tanggungjawab negara yang memiliki kaitan erat dengan Pasal 27 ayat (2) Undang-Undang Dasar Tahun 1945; kedua untuk menganalisis upaya perlindungan hukum ketenagakerjaan Indonesia ditinjau dari tanggungjawab
\end{abstract}


negara yang memiliki kaitan erat dengan Pasal 27 ayat (2) Undang-Undang Dasar Tahun 1945. Penelitian ini dilakukan dengan metode deskriptif analitis menggunakan pendekatan yuridis normatif. Aspek hukum ketenagakerjaan asing ditinjau dari tanggungjawab negara dilihat pada pengaturan atas pengendalian TKA yang hanya dapat dilaksanakan dalam hubungan kerja pada waktu tertentu. Malahan perlu ditekankan mengenai perlindungan hukum dan jaminan kesejahteraan sosial layaknya tenaga kerja dalam negeri. Selain itu, dalam hal pengawasan tenaga kerja asing seharusnya tidak ada ketimpangan hak dan kewajiban antara tenaga kerja asing dan tenaga kerja dalam negeri. Upaya perlindungan hukum ketenagakerjaan Indonesia ditinjau dari tanggungjawab negara ini dapat dilihat pada implementasi mengenai upaya mendidik dan melatih tenaga kerja dalam negeri guna meningkatkan standar kompetensi yang mampu bersaing dengan tenaga kerja asing.

Kata-kata Kunci Tenaga Kerja Asing; Tanggungjawab Negara; Pengawasan.

\section{Pendahuluan}

Dewasa ini, wacana liberalisasi pasar tenaga kerja mulai diperbincangkan di Asia Tenggara, yang ternyata sulit untuk melakukan penyeragaman dalam pembuatan peraturan mengenai pasar tenaga kerja. Hal tersebut dikarenakan masing-masing negara membuat peraturan sendiri, dan belum adanya standarisasi keterampilan kerja di kawasan Asia Tenggara. Di Indonesia sendiri, liberalisasi pasar tenaga kerja ditanggapi pemerintah dengan merevisi berbagai peraturan perundang-undangan ketenagakerjaan dimana di dalamnya mengatur TKA. ${ }^{1}$

Kondisi saat ini, Indonesia sebagai Negara berkembang masih membutuhkan investor asing. Hal tersebut juga beriringan dengan pengaruh globalisasi peradaban. Dalam hal ini, Indonesia merupakan bagian dari komunitas perdagangan dunia seperti World Trade Organization (WTO), ASEAN-China Free Trade Area (ACFTA) dan Masyarakat Ekonomi ASEAN (MEA), sehingga diharuskan turut memberikan peluang bagi tenaga kerja asing untuk masuk ke Indonesia.

Upaya untuk antisipasi hal-hal negatif yang berkaitan dengan penggunaan TKA harus didukung dengan peraturan yang lengkap, baik dari sisi aturan persyaratan TKA, maupun pengamanan penggunaan TKA. Peraturan tersebut harus mengakomodir aspek-aspek dasar serta tidak hanya peraturan yang mengatur di tingkat menteri. Hal tersebut perlu dilakukan dengan tujuan penggunaan TKA secara selektif dengan tetap memprioritaskan Tenaga Kerja Indonesia (TKI).

1 Agusmidah, Dilematika Hukum Ketenagakerjaan Tinjanan Politik. Hukum (Medan: Sofmedia, 2011), Hlm. 350. 
Kualitas tenaga kerja merupakan salah satu syarat yang dapat menentukan keberhasilan pembangunan nasional. Peningkatan kualitas tenaga kerja tersebut tidak akan terwujud apabila tidak diberikan jaminan hidup. Sedangkan jaminan hidup tidak akan terwujud pula apabila masyarakat Indonesia tidak mempunyai pekerjaan. Pasal 27 ayat (2) UUD RI 1945 berisi bahwa: "Tiap-tiap warga negara berhak atas pekerjaan dan penghidupan yang layak bagi kemanusiaan."

Ayat tersebut berarti bahwa negara bertanggungjawab untuk menyediakan sarana pendukung dalam mendapatkan pekerjaan bagi setiap warga negaranya, dengan cara menciptakan lapangan kerja seluas-luasnya dalam rangka mengurangi jumlah pengangguran di Indonesia. Masalah ketenagakerjaan telah lama terjadi di Indonesia, yaitu sebelum terselenggarakannya proklamasi kemerdekaan lebih tepatnya pada masa penjajahan Belanda.

Antisipasi pemerintah untuk menghindari penggunaan tenaga kerja asing yang berlebihan yaitu dengan membuat peraturan yang membatasi penggunaan TKA, guna memberikan ruang dan membuka peluang kerja untuk Warga Negara Indonesia (WNI). Paradigmanya, hampir setiap negara tidak dapat terlepas dari keikutsertaan dengan negara lain. Hal tersebut karena adanya keterkaitan antar negara dalam melaksanakan berbagai kepentingan. Sehingga akan timbul hubungan yang konsisten dan berkelanjutan antar negara-negara yang saling bekerjasama, hubungan inilah yang disebut hubungan diplomatik. ${ }^{2}$

Namun kenyataannya saat ini peraturan ketenagakerjaan yang ada belum memberikan gambaran yang pasti tentang pengaturan serta pengawasan terhadap mekanisme TKA yang berada pada wilayah Indonesia. Padahal, globalisasi dapat mempengaruhi prestasi tenaga kerja dikarenakan adanya penanaman modal asing atau disebut juga dengan istilah foreign direct investment ${ }^{3}$. Sehingga diperlukan adanya perhatian khusus untuk meningkatkan keahlian dan pengetahuan tenaga kerja.

Setiap tahunnya jumlah angkatan kerja semakin meningkat yang diakibatkan oleh tingginya laju pertumbuhan penduduk di Indonesia. Akan tetapi, kondisi di lapangan saat ini mencerminkan bahwasanya ketersediaan kesempatan kerja belum dapat mengakomodir para pencari kerja di Indonesia. Bahkan Pemutusan Hubungan Kerja (PHK) tebilang cukup banyak dialami oleh tenaga kerja, dan mengakibatkan banyaknya pengangguran di Indonesia. Hal tersebut dapat mengurangi kesempatan kerja bagi tenaga profesional dalam negeri. Dengan demikian, konsistensi pemerintah dalam membuat kebijakan mengenai pengaturan TKA di Indonesia perlu dipertanyakan.

Tujuan penelitian ini adalah, pertama untuk menganalisis aspek hukum ketenagakerjaan asing ditinjau dari tanggungjawab negara yang memiliki kaitan erat dengan Pasal 27 ayat (2) UUD RI 1945; kedua untuk menganalisis upaya

2 Narsif, Hukum Diplomatik Konsuler (Padang: Universitas Andalas, 2007), Hlm. 1.

3 Agusmidah, Hukum Ketenagakerjaan Indonesia: Dinamika Dan Kajian Teori (Bogor: Ghalia Indonesia, 2010), Hlm. 111. 
perlindungan hukum ketenagakerjaan Indonesia ditinjau dari tanggungjawab negara yang memiliki kaitan erat dengan Pasal 27 ayat (2) UUD RI 1945.

Sebetulnya telah banyak kajian serupa mengenai TKA di Indonesia, kajian yang dilakukan oleh Jazuli ${ }^{4}$ menjabarkan belum optimalnya pelaksanaan peraturan perundang-undangan mengenai pengendalian serta pengawasan TKA. Terutama dalam hal koordinasi yang seharusnya dilakukan oleh instansi terkait sehingga berdampak pada meningkatnya pelanggaran keimigrasian yang dilakukan TKA. Kajian serupa dilakukan oleh Suhandi ${ }^{5}$ menjabarkan bahwa seharusnya pelaksanaan peraturan hukum ketenagakerjaan betul-betul diimplementasikan dalam penggunaan TKA. Implementasi tersebut misalnya memberikan batasan kepada TKA dalam menduduki jabatan-jabatan tertentu. Dimana TKA dituntut harus memiliki standar kompetensi dengan batasan jangka waktu bekerja serta memiliki tenaga pendamping TKI. Peraturan tersebut seharusnya diterapkan secara efektif sehingga di lapangan semua pekerjaan tidak dikerjakan oleh TKA, apabila ini terjadi maka TKI hanya sebagai penonton di negaranya sendiri.

Kajian serupa mengenai TKA kaitannya dengan rancangan UndangUndang Cipta Kerja (UU Cipta Kerja) telah dilakukan oleh Hanifah ${ }^{6}$. Pada kajian tersebut, penulis menyimpulkan bahwa sahnya UU Cipta Kerja berdampak pada pemangkasan izin masuk TKA. Sehingga kini, TKA hanya membutuhkan Penggunaan Tenaga Kerja Asing (RPTKA) saja. Kemudian di Pasal 46 UU Nomor 13 Tahun 2003, TKA dilarang menduduki jabatan yang mengurusi personalia dan jabatan tertentu yang rinciannya diatur Keputusan Menteri. Di UU Cipta Kerja, dilakukan penghapusan pasal mengenai pembatasan jabatan untuk TKA di perusahaan Indonesia yakni Pasal 46 Undang-Undang Nomor 13 Tahun 2003 tentang Ketenagakerjaan (UU Nomor 13 Tahun 2003).

Meskipun telah banyak penelitian serupa lainnya dalam membahas TKA di Indonesia, penelitian ini berfokus pada bahasan mengenai aspek hukum TKA di Indonesia dari sisi tanggung jawab negara serta upaya perlindungan hukum TKI agar mampu berkompetisi dengan TKA di negaranya sendiri. Sehingga harapannya dengan adanya kajian ini, dapat berkontribusi untuk kebaruan referensi ilmiah dalam kajian ketenagakerjaan di Indoneisa khususnya mengenai TKA di Indonesia serta perlindungan hukum untuk TKI kaitannya dengan Pasal 27 ayat (2) UUD RI 1945.

4 Ahmad Jazuli, "Eksistensi Tenaga Kerja Asing di Indonesia Dalam Perspektif Hukum Keimigrasian," JIKH 12, no. 1 (2018).

5 Suhandi, "Pengaturan Ketenagakerjaan Terhadap Tenaga Kerja Asing Dalam Pelaksanaan Masyarakat Ekonomi ASEAN di Indonesia," Jurnal Perspektif XXI, no. 2 (2016).

6 Ida Hanifah, "Peluang Tenaga Kerja Asing Untuk Bekerja di Indonesia Berdasarkan Rancangan Undang-Undang Cipta Kerja,” Delegalata Jurnal Ilmu Hukum 6, no. 1 (2021). 


\section{Metodologi}

Metode penelitian ini dilakukan secara deskriptif analitis yang artinya kajian ini berupaya menggambarkan secara komprehensif dan mendalam mengenai kondisi atau gejala yang menjadi objek penelitian. Selain itu, penelitian ini juga berupaya untuk menentukan keterkaitan antara suatu gejala dengan gejala lainnya di lingkungan masyarakat ${ }^{7}$. Metode pendekatan yang digunakan adalah yuridis normatif artinya kajian dilaksanakan melalui pengkajian atau penelaahan peraturan perundang-undangan, teori-teori hukum dan yurisprudensi yang berkaitan dengan problematika yang dikaji serta hubungannya dengan implementasinya dalam praktek ${ }^{8}$. Dalam kajian ini, perundang-undangan serta peraturan yang dikaji adalah Pasal 27 ayat (2) UUD RI 1945, UU Nomor 13 Tahun 2003, UU Nomor 11 Tahun 2020 serta Permenaker Nomor 10 Tahun 2018.

Adapun pengumpulan sumber data, peneliti melakukan pengumpulan dalam wujud data primer melalui wawancara (interview) dan data sekunder melalui studi pustaka atau literatur. Jenis data yang dikumpulkan dalam penelitian ini adalah data kualitatif yaitu data yang berupa kalimat-kalimat tertulis yang menggambarkan pokok permasalahan yang berkaitan dengan masalah penelitian. Pengumpulan data primer melalui wawancara dilakukan di Dewan Perwakilan Rakyat Daerah (DPRD) Provinsi Jawa Barat dengan informan bernama Herlas Juniar sebagai Anggota DPRD Provinsi Jawa Barat. Adapun pengumpulan data sekunder diperoleh dari berbagai peraturan, buku, artikel jurnal serta website resmi.

\section{Hasil dan Pembahasan}

\section{Aspek Hukum Ketenagakerjaan Asing dari Tanggungjawab Negara}

Pasal 27 ayat (2) UUD RI 1945 yang berbunyi "Tiap-tiap warga negara berbak atas pekerjaan dan penghidupan yang layak bagi kemanusiaan" menekankan pada jaminan dan perlindungan hak warga negara dalam hal pekerjaan dan seluruh penunjang kehidupan yang layak dalam ukuran kemanusiaan. Pasal ini penting bagi keberlangsungan hidup setiap warga negara dan merupakan bagian dari tanggungjawab negara terhadap warga negaranya.

Frasa "berbak atas" dalam pasal tersebut ditelaah sebagai makna bahwa seseorang berhak memiliki haknya yang telah disediakan atau sudah ada sebelumnya. Ini berbeda dengan makna "berbak" atau "berbak memiliki" yang maksudnya seseorang dapat memiliki hak namun hak tersebut masih harus

7 Soerjono Soekanto dan Sri Mamudji, Penelitian Hukum Normatif - Suatu Tinjanan Singkat (Jakarta: Raja Grafindo Persada, 2004), 10.

8 Ronny Hanitijo Soemitro, Metodologi Penelitian Hukum dan Jurimetri (Jakarta: Ghalia Indonesia, 1990), 97. 
dicari untuk bisa mendapatkannya. Sementara "berhak atas pekerjaan" dalam Pasal 27 ayat (2) UUD RI 1945 ini menekankan bahwa pekerjaan berhak didapatkan warga negara tanpa perlu mencarinya dengan penghasilan karena telah disediakan oleh negara.

Sementara frasa "penghidupan yang layak bagi kemanusiaan" memiliki makna mengenai sarana pendukung untuk kehidupan yang layak bagi standar kehidupan manusia. Hal tersebut menunjukkan bahwa negara memiliki kewajiban dan tanggungjawab dalam penyediaan lapangan kerja dengan pendapatan yang layak serta kehidupan yang berkemanusiaan.

Konsep kepemilikan hak yang sama untuk memperoleh pekerjaan berdasarkan UUD RI 1945 adalah sebuah mata rantai antara hak dengan kewajiban yang harus berfungsi menurut posisinya masing-masing. Adanya persamaan hak dalam mendapatkan pekerjaan yang layak artinya setiap warga negara harus mendapatkan keadilan yang sama dari pemerintah. Sementara itu, warga negara memiliki kewajiban juga untuk mematuhi hukum serta aturan yang berlaku. Walaupun di samping itu warga Negara juga diberikan kebebasan dalam menuntut haknya. Namun kebebasan tersebut bukan seperti kebebasan demokrasi barat. Akan tetapi, kebebasan dalam konteks WNI adalah kebebasan untuk bertanggungjawab. Begitu pula pemerintah yang memiliki hak dalam memberikan tindakan pada warga negaranya sepanjang mampu dipertanggungjawabkan.

Subjek "setiap orang" mempunyai arti luas yaitu negara wajib melindungi TKI dan TKA. Namun, dalam Pasal 27 ayat (2) UUD RI 1945 menggunakan subjek "tiap-tiap warga" yang mempunyai arti spesifik yaitu negara lebih mementingkan dan melindungi TKI. Hal tersebut dalam rangka mengembangkan negara bukan merendahkan negara. ${ }^{9}$

Perlindungan hukum terhadap tenaga kerja pada hakikatnya adalah bagian dari pemenuhan hak dasar yang melekat dan dilindungi dalam konstitusi sebagaimana diatur pada Pasal 27 ayat (2) UUD RI 1945. Tiap warga negara, baik warga Indonesia maupun asing, haruslah memiliki kepastian hukum di dalamnya yang memberikan rasa keadilan. Seperti dalam aspek keamanan dan aspek legalitas, kehadiran TKA tidak seharusnya dilihat sebagai ancaman bagi TKI, sebaliknya justru seharusnya dijadikan sebagai pemicu bagi TKI untuk lebih professional dan meningkatkan diri agar dapat bersaing baik antara sesama TKI dan TKA. Oleh karenanya UU Nomor 13 Tahun 2003 membatasi jabatanjabatan yang dapat diduduki oleh TKA.

Dalam konteks pra hubungan kerja, pengawasan terhadap pengaturan mengenai hubungan kerja bagi tenaga kerja asing terkait adanya rincian atau pembatasan pekerjaan merupakan bentuk jaminan kepastian hukum dari negara. Namun dalam masa tersebut, tanggungjawab negara adalah memenuhi hak-hak

9 Herlas Juniar, “Wawancara Dengan Anggota DPRD Provinsi Jawa Barat,” (2018). 
TKA di Indonesia, seperti 1) memperoleh fasilitas sebagai seorang tenaga kerja; 2) memperoleh upah yang memenuhi standar upah lokal, nasional, regional, ataupun internasional; 3) memiliki hak dalam memilih jalan hidupnya sendiri termasuk dalam menentukan pasangan hidupnya baik sebagai suami atau istri; dan 4) memiliki hak dalam menerima perlakuan yang layak sebagai seorang masyarakat yang membutuhkan kehidupan bersama dengan orang lain yang berbeda warga negara. ${ }^{10}$

Konteks pra hubungan kerja ini artinya TKA seharusnya betul-betul sah dalam kepemilikan status kedudukan yang sah dan memberi manfaat bagi pembangunan nasional. Berangkat dari hal tersebut, dalam konteks pada masa dalam hubungan kerja, tanggungjawab negara terhadap TKA seharusnya mampu mengakomodasi hak atas pekerjaan dimana dalam menjalankan tugasnya sudah ditetapkan standar kehidupan yang layak bagi warga negara.

Selain itu, dalam penempatan TKA harus memiliki akses atas pekerjaan dimana TKA bebas dari pelanggaran Hak Asasi Manusia (HAM) seperti kerja paksa, praktik perbudakan dan praktik yang disamakan dengan perbudakan, jeratan hutang, perdagangan orang, dan pernikahan paksa. Tanggungjawab negara dalam hal ini akan terimplementasi dengan baik apabila pemenuhan hakhak dasar TKA yang tertuang dalam Undang-Undang Nomor 13 Tahun 2003, yakni kesempatan dan perlakuan yang sama dalam hubungan kerja telah terpenuhi.

\section{Upaya Perlindungan Hukum Ketenagakerjaan Indonesia}

Pesatnya perkembangan teknologi di era globalisasi membuat jumlah pesaing pekerja meningkat baik lokal maupun internasional. Dampak dari hal tersebut berimbas pada perusahaan yang juga berlomba-lomba meningkatkan manajemen dengan menonjolkan kualitas Sumber Daya Manusia (SDM). Namun dengan derasnya arus investasi asing di Indonesia membuat beberapa perusahaan lebih memilih memenuhi kebutuhan penggunaan tenaga kerja profesional dan ahli yang berasal dari negara asal perusahaan.

Pergerakan penggunaan TKA pada perusahaan-perusahaan yang berdiri di Indonesia ini perlu dikendalikan dan diawasi oleh negara, agar tidak terjadi masalah hukum dan penggunaan TKA yang berlebihan. Pemerintah harus mengatur kebijakan mengenai TKA dengan model selective policy. Utamanya juga terkait perizinan dan penggunaan tenaga kerja asing pada unskill labour.

Namun, peran negara terkait permasalahan ketenagakerjaan tersebut belum maksimal karena masih terpengaruh oleh faktor penyebab terjadinya

10 Chandra Putra Kuriawan, "Pemegang Hak Tenaga Kerja Asing dalam Perspektif Hak Asasi Manusia," Jurnal JIPPK 3, no. 1 (n.d.): Hlm. 32. 
TKA berlebih di Indonesia, antara lain: $\left.{ }^{11} 1\right)$ faktor keterbukaan investasi, mengingat Indonesia sedang banyak melakukan pembangunan yang mendatangkan investor satu paket dengan tenaga kerjanya mulai dari manager sampai buruh kasar; 2) faktor kebijakan bebas visa; dan 3) faktor berlakunya MEA yang berakibat pada hilangnya batasan antar negara serta meningkatnya keberadaan TKA di Indonesia.

Oleh karenanya dalam penggunaan TKA perlu dilakukan mekanisme yang ketat dan tidak mencederai amanat Pasal 27 ayat (2) UUD RI 1945. Pada tingkatan konstitusional, perlindungan tenaga kerja Indonesia lebih khusus memang terletak pada Pasal 27 ayat (2) UUD RI 1945. Pengaturan secara nasional mengenai ketenagakerjaan sejauh ini hanya berlandaskan UU Nomor 13 Tahun 2003 yang bahkan masih belum diharmonisasikan dengan peraturan lainnya. Pada implementasinya memang beberapa kebijakan yang diambil umumnya bersifat sporadic dan jarang memecahkan problematika di lapangan. Padahal setidak-tidaknya diperlukan langkah-langkah strategis dalam implementasi kebijakan seperti: ${ }^{12}$ 1) melakukan penggabungan rencana tindakan dari suatu program dengan menetapkan tujuan, standar pelaksana, waktu serta biaya yang jelas; 2) mengimplementasikan program dengan memobilisasi struktur, resources, staf, prosedur, biaya serta metode; dan 3) membuat jadwal pelaksanaan serta monitoring untuk menjamin bahwa program tersebut berjalan terus sesuai dengan perencanaan.

Pada Peraturan Presiden Nomor 20 Tahun 2018 tentang Penggunaan Tenaga Kerja Asing (Perpres Nomor 20 Tahun 2018) yang justru tidak sesuai dengan UU Nomor 13 Tahun 2003. Ketentuan pada Pasal 9 Perpres Nomor 20 Tahun 2018 menyebutkan bahwa adanya pengesahan RPTKA ini merupakan izin untuk mempekerjakan TKA. Artinya badan usaha atau perusahaan yang ingin menggunakan TKA tidak wajib untuk mengurus izin. Bertentangan dengan Pasal 43 ayat (1) UU Nomor 13 Tahun 2003 di mana: "Pemberi kerja yang mau mempergunakan tenaga kerja asing ini harus memiliki RPTKA yang disahkan oleh menteri atau pejabat yang ditunjuk".

Penjelasan pada Pasal 43 ayat (1) UU Nomor 13 Tahun 2003 tersebut menjelaskan bahwa RPTKA dan Izin Menggunakan Tenaga Asing (IMTA) adalah dua hal berbeda, di mana RPTKA merupakan syarat yang kemudian untuk mendapat izin. Sementara izin dijabarkan dalam ketentuan Pasal 42 ayat (1) UU Nomor 13 Tahun 2003 sebagai berikut: "Setiap pemberi kerja yang mempekerjakan tenaga kerja asing wajib memiliki izin tertulis dari menteri atau pejabat yang ditunjuk untuk mengesahkannya."

11 Nurhidayati, "Perizinan Tenaga Kerja Asing, Kebijakan dan Implementasinya," Widya Cipta: Jurnal Sekretari Dan Manajemen 3, no. 2 (2019): Hlm. 247.

12 Rizky Dian Bareta, "Politik Hukum Perlindungan Tenaga Kerja Indonesia Fase Purna Bekerja," Kanun Jurnal Ilmu Hukum 20, no. 1 (2018): 173, https://doi.org/10.24815/kanun.v20i1.9828. 
Adapun pengesahan RPTKA dapat dilakukan oleh dirjen untuk pemberi kerja TKA yang mempekerjakan TKA sebanyak 50 (lima puluh) orang atau lebih dan direktur untuk pemberi kerja TKA yang mempekerjakan TKA kurang dari 50 (lima puluh) orang. Sementara, SK Pengesahan RPTKA memuat alasan penggunaan TKA, jabatan dan/atau kedudukan TKA, lokasi kerja TKA, upah/gaji TKA, jumlah TKA, jangka waktu penggunaan TKA, jumlah TKI yang ditunjuk sebagai TKI pendamping, serta jumlah TKI yang dipekerjakan. ${ }^{13}$

\section{Tabel 1. Perbandingan Pengaturan Tenaga Kerja Asing Dalam Peraturan Perundang-Undangan}

\begin{tabular}{|c|c|c|}
\hline UU Nomor 13 Tahun 2003 & UU Nomor 11 Tahun 2020 & $\begin{array}{c}\text { Permenaker Nomor } 10 \\
\text { Tahun } 2018\end{array}$ \\
\hline $\begin{array}{l}\text { Pasal } 42 \text { ayat (1) } \\
\text { menyebutkan bahwa pemberi } \\
\text { kerja yang mempekerjakan } \\
\text { TKA wajib memiliki izin } \\
\text { tertulis dari Menteri atau } \\
\text { Pejabat yang ditunjuk. }\end{array}$ & $\begin{array}{l}\text { Pasal } 42 \text { ayat (1) menyebutkan } \\
\text { bahwa pemberi kerjar yang } \\
\text { mempekerjakan TKA wajib } \\
\text { memiliki RPTKA yang disahkan } \\
\text { oleh Pemerintah Pusat. Ketentuan } \\
\text { IMTA dihapus. }\end{array}$ & $\begin{array}{l}\text { Pasal } 32 \text { ayat (2) menyebutkan } \\
\text { bahwa data penggunaan TKA } \\
\text { meliputi Pengesahan RPTKA } \\
\text { dan Notifikasi Penggunaan } \\
\text { TKA. Ketentuan IMTA } \\
\text { dihapus. }\end{array}$ \\
\hline $\begin{array}{l}\text { Pasal } 42 \text { ayat }(3) \\
\text { menyebutkan bahwa } \\
\text { kewajiban memiliki RPTKA } \\
\text { dikecualikan bagi perwakilan } \\
\text { negara asing yang } \\
\text { mempergunakan tenaga kerja } \\
\text { asing sebagai pegawai } \\
\text { diplomatik dan konsuler. }\end{array}$ & $\begin{array}{l}\text { Pasal } 42 \text { ayat (3) diperluas bahwa } \\
\text { pengecualian atas RPTKA berlaku } \\
\text { untuk: } \\
\text { a. Direksi atau komisaris dengan } \\
\text { kepemilikan saham sesuai dengan } \\
\text { ketentuan perundang-undangan; } \\
\text { b.Pegawai diplomatik dan konsuler } \\
\text { pada kantor perwakilan negara } \\
\text { asing; yang dibutuhkan oleh } \\
\text { c. TKA yang } \\
\text { pemberi kerja pada jenis kegiatan } \\
\text { produksi yang terhenti karena } \\
\text { keadaan darurat, vokasi, } \\
\text { perusahaan rintisan (start-up) } \\
\text { berbasis teknologi, kunjungan } \\
\text { bisnis, dan penelitian untuk } \\
\text { jangka waktu tertentu. }\end{array}$ & $\begin{array}{l}\text { Pasal } 10 \text { ayat (1) menyebutkan } \\
\text { bahwa kewajiban memiliki } \\
\text { RPTKA dikecualikan bagi: } \\
\text { a. Instansi pemerintah, } \\
\text { perwakilan negara asing, dan } \\
\text { badan internasional; } \\
\text { b.Pemberi kerja TKA yang } \\
\text { mempekerjakan TKA } \\
\text { sebagai anggota direksi atau } \\
\text { anggota dewan komisaris } \\
\text { dengan kepemilikan saham } \\
\text { sesuai dengan ketentuan } \\
\text { peraturan perundang- } \\
\text { undangan. }\end{array}$ \\
\hline \begin{tabular}{lrr} 
Pasal 43 & ayat & $(1)$ \\
menyebutkan & & bahwa \\
pemberi & kerja & yang \\
menggunakan & TKA & harus \\
memiliki & \multicolumn{2}{r}{ rencana } \\
penggunaan TKA (RPTKA)
\end{tabular} & Pasal 43 dihapus. & $\begin{array}{l}\text { Pasal } 4 \text { ayat (4) huruf a dan } \\
\text { Pasal } 9 \text { ayat (1) menyebutkan } \\
\text { bahwa pemberi kerja yang } \\
\text { menggunakan TKA harus } \\
\text { memiliki rencana penggunaan } \\
\text { TKA (RPTKA) yang disahkan } \\
\text { oleh Menteri atau Pejabat yang } \\
\text { ditunjuk. }\end{array}$ \\
\hline $\begin{array}{l}\text { Pasal } 44 \text { ayat } \begin{array}{r}(1) \\
\text { menyebutkan }\end{array} \text { bahwa } \\
\text { pemberi kerja TKA wajib } \\
\text { menaati ketentuan mengenai } \\
\text { jabatan dan standar } \\
\text { kompetensi yang berlaku. }\end{array}$ & Pasal 44 dihapus. & $\begin{array}{l}\text { Pasal-pasal pada Bagian Ketiga } \\
\text { Jabatan dan Sektor Tertentu. }\end{array}$ \\
\hline
\end{tabular}

13 Risky Vista Puspita Sari, "Kepastian Hukum Pengaturan Penggunaan Tenaga Kerja Asing Di Indonesia," Lentera Hukum 5, no. 3 (2018): 370. 
Sumber : UU Nomor 13 Tahun 2003, UU Nomor 11 Tahun 2020 dan Permenaker Nomor 10 Tahun 2018

Semakin menuju ke arah pembangunan, pengaturan mengenai ketenagakerjaan ini pun menyesuaikan yang pada akhirnya kemunculan Perpres Nomor 20 Tahun 2018 disertai dengan Peraturan Menteri Ketenagakerjaan Nomor 10 Tahun 2018 tentang Tata Cara Penggunaan Tenaga Kerja Asing (Permenaker Nomor 10 Tahun 2018) ada untuk mendukung perekonomian dan pembangunan nasional, serta peningkatan investasi. Pengaturan tersebut hadir untuk kemajuan perekonomian nasional dan untuk memperluas dan menambahkan kesempatan kerja melalui peningkatan/strategi investasi. ${ }^{14}$

Regulasi terbaru penggunaan TKA sejak diterbitkannya Undang-Undang Nomor 11 Tahun 2020 tentang Cipta Kerja (UU Nomor 11 Tahun 2020) mengubah dan menghapus beberapa-berapa pasal dalam UU Nomor 13 Tahun 2003 yang jutru mempermudah TKA masuk ke Indonesia, diantaranya: 1) diubahnya bunyi Pasal 42 menjadi TKA hanya perlu memiliki RPTKA yang disahkan oleh Pemerintah Pusat saja karena tidak lagi memerlukan izin tertulis dari menteri atau pejabat yang ditunjuk; 2) dihapusnya Pasal 43 mengenai RPTKA sekurang-kurangnya memuat keterangan alasan penggunaan TKA, jabatan TKA di perusahaan, jangka waktu penggunaan TKA, dan penunjukan WNI sebagai pendamping; dan 3) dihapusnya Pasal 44 yang mewajibkan perusahaan pemberi kerja TKA untuk menaati ketentuan mengenai jabatan serta standar kompetensi yang berlaku yang diatur dalam Keputusan Menteri.

Pada dasarnya hukum ketenagakerjaan hendak mewujudkan keadilan sosial bagi seluruh rakyat dan hal tersebut berdasarkan pada dua aspek yaitu: 1) hukum secara ideal diwujudkan melalui peraturan perundang-undangan (heteronom) dan yang bersifat otonom. Pada ranah hukum ini harus merepresentasikan produk hukum yang sesuai das sollen sesuai keadilan dan kebenaran, berkepastian, dan memiliki manfaat bagi para pihak. Peraturan perundang-undangan tersebut nantinya akan selaras dengan makna keadilan pada Pasal 27 ayat (2) UUD RRI 1945; dan 2) implementasi dari hukum normatif memberi kontribusi dalam bentuk pengawasan melalui instrumen struktur (penegak hukum) serta melakukan penindakan pada pihak-pihak yang tidak patuh pada ketentuan hukum.

Bagaimanapun Perlindungan Ketenagakerjaan di Indonesia harus memiliki kepastian hukum yang tercantum pada tiap peraturan mengenai TKA. Menurut Sudikno Mertokusumo, kepastian hukum ini adalah jaminan bahwa hukum dijalankan dan yang berhak menurut hukum dapat memperoleh haknya

14 S Atalim dan Shierly Debora, "Tinjauan Hukum Terhadap Penggunaan Tenaga Kerja Asing di Indonesia Berdasarkan Pengaturan yang Dibuat oleh Presiden Nomor 20 Tahun 2018 Jo. Peraturan Menteri Ketenagakerjaan Nomor 10 Tahun 2018," Era Hukum Jurnal Ilmiah Ilmu Hukum 17, No. 2 (2019): Hlm. 238. 
dan bahwa putusan dapat dilaksanakan. ${ }^{15}$ Lon Fuller juga menyebutkan bahwa dalam hal harus dipenuhi oleh hukum ada 7 (tujuh) asas yang harus dipenuhi, yakni: 1) suatu sistem hukum yang terdiri dari peraturan-peraturan, tidak berdasarkan putusan-putusan sesaat untuk hal-hal tertentu; 2) peraturan tersebut diumumkan ke publik; 3) tidak berlaku surut, karena akan merusak integritas sistem; 4) dibuat dalam rumusan yang dimengerti oleh umum; 5) tidak boleh ada peraturan yang saling bertentangan; 6) tidak boleh menuntut suatu tindakan yang melebihi apa yang bisa dilakukan; dan 7) harus ada kesesuaian antara peraturan dan pelaksanaan sehari-hari. ${ }^{16}$

Beberapa peraturan telah ditetapkan untuk mengatur aspek-aspek dasar dan bentuk peraturan yang mengatur tujuan penggunaan TKA secara selektif dengan memprioritaskan TKI. UU Nomor 13 Tahun 2003 tidak mengatur TKA secara rinci, sehingga sejumlah pengaturan tersebut didelegasikan dengan aturan-aturan pelaksana. Jadi pengaturan TKA sangat fleksibel yang akhirnya berdampak pada mudah dilakukannya perubahan aturan-aturan tersebut.

Indonesia sebagai negara hukum yang menjunjung tinggi HAM mengutamakan perlindungan terhadap TKI yang sudah dijamin melalui konstitusi. Pasal 28 D ayat (2) UUD RI 1945 menyebutkan bahwa: "Setiap orang berhak untuk bekerja serta mendapat imbalan dan perlakuan yang adil dan layak dalam hubungan kerja."

Hak untuk pekerja dan hak-hak dalam pekerjaan sekarang bukan sekedar hak sosial ekonomi semata, namun merupakan hak manusia yang fundamental. Ini berimplikasi pada negara untuk menunaikan tanggungjawabnya untuk memfasilitasi serta melindungi warga negara agar dapat memperoleh penghasilan sesuai standar penghidupan yang layak. Oleh karenanya, negara perlu perencanaan yang matang untuk mewujudkan kewajiban negara tersebut.

Hal ini sebagai bagian dari pembangunan ketenagakerjaan yang diarahkan untuk menjamin hak-hak tenaga kerja serta menjamin kesamaan kesempatan serta perlakuan tanpa diskriminatif atas dasar apapun untuk mewujudkan kesejahteraan pekerja dan keluarganya dengan tetap memperhatikan perkembangan kemajuan dunia usaha. ${ }^{17}$ Untuk mencapai hal tersebut, diperlukan penunjang seperti tatanan hukum yang mendorong dan menggerakkan pembangunan tersebut. Hukum selanjutnya harus dipandang sebagai sarana pembaharuan masyarakat yang harus selalu dapat memberikan arah yang melindungi, mengatur, mendorong, merencanakan, menggerakkan dan mengendalikan masyarakat sesuai tahapan pembangunan.

15 Sudikno Mertokusumo, Mengenal Hukum Suatu Pengantar (Yogyakarta: Liberty, 2007), hlm. 13.

16 Mertokusumo, Hlm. 375.

17 Konsideran 'Menimbang' Huruf d Undang-Undang Nomor 13 Tahun 2003 Tentang Ketenagakerjaan. 
Salah satu akar permasalahan dari TKI dapat dilihat dari adanya ketimpangan antara lapangan pekerjaan dengan SDM yang ada. Data lapangan memperlihatkan bahwa pengangguran terdidik masih mempunyai angka cukup besar sehingga membuat pengangguran yang tingkat pendidikannya SMA ke bawah bertarung dua kali lipat untuk memperebutkan lapangan pekerjaan. Hal tersebut yang kemudian mendorong keberadaan tenaga kerja Indonesia bekerja ke luar negeri dengan menimbang lapangan pekerjaan yang tersedia di sana dan tingkat penghasilan yang cukup tinggi. Motif ekonomi dari individu semacam ini yang selanjutnya membawa ekonomi negara berkembang karena adanya pertambahan devisa negara. Satu sisi hal ini tentu harus dibarengi perlindungan hukum bagi tenaga kerja migran Indonesia.

TKI dan TKA mempunyai kaitan erat karena terhitung sejak Agustus 2020 tingkat pengangguran di Indonesia melonjak cukup tinggi dengan jumlah 9,77 juta. ${ }^{18}$ Jumlah ini meningkat 1,84\% jika dibandingkan dengan data Agustus 2019. Maksudnya prioritas negara di sini tentu adalah tenaga kerja dalam negeri diberikan kesempatan kerja dibandingkan dengan penggunaan TKA. Sementara data TKA tercatat pada Jumlah TKA di Indonesia pada 2020 mencapai 98.902 orang. Dari data tersebut TKA asal China menduduki peringkat pertama, yaitu 35.781 orang. atau setara $36,17 \% .{ }^{19}$ Fakta lainnya, terjadi kesenjangan upah dalam proyek kereta cepat di Rancaekek, dimana TKI diberi upah Rp 100.000/hari sementara TKA diberi upah Rp 800.000/hari padahal posisi TKI dan TKA tersebut sama-sama sebagai pekerja kasar, sehingga tidak ada yang namanya alih pengetahuan. Selain itu bahasa yang digunakan oleh TKA masih memakai bahasa yang digunakan di negaranya. ${ }^{20}$

Perlindungan hukum ketenagakerjaan yang diatur dalam Undang-Undang Ketenagakerjaan dilihat dari tiga aspek, yaitu: 1) aspek perlindungan sosial; 2) perlindungan ekonomis, dan 3) perlindungan teknis (keselamatan kerja). ${ }^{21}$ Secara struktural, peran negara di sini memang tidak hanya sekadar membuat peraturan perundang-undangan semata, tetapi juga ke pelaksanaan peraturan yang telah dibuat hingga dapat diwujudkan menjadi kenyataan. Salah satu bentuk tanggungjawab negara dapat dilihat di bidang ekonomi dan kesejahteraan sosial atas pekerjaan dan penghidupan yang layak bagi kemanusiaan untuk warga negaranya. Ini berhubungan dengan dasar kesejahteraan dan keadilan. Sehingga pekerjaan yang ada layak bagi kemanusiaan dan tidak

18 Badan Pusat Statistik, “Agustus 2020: Tingkat Pengangguran Terbuka (TPT) Sebesar 7,07 Persen,” https:/ / wnw.bps.go.id/pressrelease/2020/11/05/1673/agustus-2020--tingkeatpengangguran-terbuka-tpt--sebesar-7-07-persen.html, diakses 23 Desember 2020.

19 Kontan.co.id, "Jumlah Tenaga Kerja Asing di Indonesia 98.902, TKA China Terbesar", https:/ / nasional.kontan.co.id/ news/jumlah-tenaga-kerja-asing-di-indonesia-98902-tka-china-terbesarberikut-datanya, diakses 23 Desesmber 2020.

20 Wawancara dengan Topik (Pekerja Proyek Kereta Cepat Rancaekek), Tanggal 16 Agustus 2020 di Transportasi Online.

21 Zainal Asikin, Dasar-Dasar Hukum Perburuban (Jakarta: Raja Grafindo Persada, 2002), 76-77. 
merendahkan harkat serta martabat manusia dalam mengusahakan warga negara untuk mendapat pekerjaan yang layak sesuai kesanggupan dan kemampuan pengupahan yang adil.

Upaya negara dalam memberikan perlindungan terhadap tenaga kerja dalam negeri ini perlu diberikan kepastian juga. Sebab hal ini berimplikasi pada kepastian kesejahteraan TKI di tengah maraknya kedatangan TKA. Negara memiliki tanggungjawab untuk meningkatkan mutu kualitas SDM agar tidak tertinggal daya saing di mana hal ini merupakan bagian dari perlindungan skill. Namun, secara sosial ekonomi, negara perlu hadir dalam hal seperti perlindungan terhadap upah kerja, perlindungan terhadap keselamatan kerja, perlindungan terhadap reproduksi tenaga kerja perempuan atau jaminan kenaikan jabatan.

Regulasi yang mengatur mengenai TKI ini tidak terpatok sebatas undangundang sebab dalam implementasinya perlu dijabarkan juga dalam peraturan pelaksana yang fleksibel sehingga akan mudah dilakukan perubahan aturanaturan tersebut. Perlindungan hukumnya perlu memenuhi asas keadilan yang dalam hal ini bertujuan agar hak-hak dasar tenaga kerja terpenuhi.

Terkait regulasi yang berkaitan dengan TKI yang bekerja di luar negeri juga diakomodasi dengan adanya Undang-Undang Nomor 18 Tahun 2017 tentang Perlindungan Pekerja Migran Indonesia (UU Nomor 18 Tahun 2017). Hanya saja implementasi dari perlindungan pekerja migran selalu terganjal dengan tidak adanya aturan pelaksana yang akan menjadi benteng untuk kegiatan calo-calo dalam rangka merekrut tenaga kerja di daerah. Secara eksplisit, UU Nomor 18 Tahun 2017 mengatur bahwa tanggungjawab negara dalam hal ini pemeritnah daerah provinsi meliputi penyelenggaraan pendidikan dan pelatihan kerja untuk calon TKI, pengurusan kepulangan TKI apabila terjadi peperangan, wabah penyakit atau bencana alam. Selain itu pemerintah juga mengatur dan mengawasi penyelenggaraan penempatan pekerja migran.

UU Nomor 18 Tahun 2017 dapat dikatakan memiliki esensi sebagai implementasi dari amanat Pasal 27 ayat (2) UUD RI 1945. Karena itu, negara harus memberikan perlindungan hukum pada warga negaranya yang akan menggunakan hak mereka untuk mendapat pekerjaan, terutama di luar negeri. Selain itu tentu adanya undang-undang tersebut menjadi sebuah revolusi ketenagakerjaan yang menggantikan ordonansi Staatsblad tahun 1887 Nomor 8 mengenai Pengerahan Orang Indonesia untuk Melakukan Pekerjaan di Luar Indonesia, juga menggantikan Undang-Undang Nomor 39 Tahun 2004 tentang Penempatan dan Perlindungan Tenaga Kerja Indonesia di Luar Negeri (UU Nomor 39 Tahun 2004). Hal lain yang patut diapresiasi dari keberadaan undang-undang tersebut adalah tata kelola migrasi tenaga kerja terutama dengan adanya penguatan peran dan tanggungjawab negara.

Salah satu upaya terbaik dari negara dalam mensejahterakan warga negaranya baik di dalam negeri dan di luar negeri adalah dengan menciptakan 
lapangan kerja dalam negeri. Namun hal tersebut menjadi sedikit terhambat karena berdasarkan laporan International Labour Organization (ILO) bahwa kondisi sosio-ekonomi antar satu provinsi dengan provinsi lain di Indonesia memiliki perbedaan serta desentralisasi pembuatan kebijakan yang masingmasing. Sehingga dibutuhkan adanya intervensi kebijakan yang tepat di tingkat daerah. ${ }^{22}$ Namun dalam UU Nomor 18 Tahun 2017 telah mengakomodasi penguatan tanggungjawab pemerintah dari tingkat pusat hingga ke tingkat daerah (provinsi hingga desa). Hal ini memperlihatkan komitmen untuk menghadirkan negara dalam perlindungan TKI yang bekerja di luar negeri dan mengakhiri tata kelola migrasi tenaga kerja yang sentralisasi dan eksploitatif.

Tanggungjawab negara berdasarkan Pasal 27 ayat (2) UUD RI 1945 tercermin pada tugas dan tanggungjawab yang mulai terdesentralisasi pada tingkatan pemerintah provinsi, seperti: 1) memberikan perlindungan pada tenaga kerja migran baik sebelum dan setelah bekerja; 2) menerbitkan izin kantor cabang perusahaan tenaga kerja migran dan melaporkan hasil evaluasinya secara berjenjang; 3) mengatur, membina, melaksanakan dan megawasi penyelenggaraan penempatan tenaga kerja migran; 4) membentuk layanan terpadu satu atap dalam hal penempatan dan perlindungan tenaga kerja migran; 5) menyediakan pos bantuan dan pelayanan di tempat pemberangkatan dan pemulangan tenaga kerja migran; dan 6) menyelenggarakan pendidikan dan pelatihan kerja.

Dari hal tersebut terlihat komitmen dan usaha negara untuk hadir dalam memberikan perlindungan bagi tenaga kerja migran Indonesia dan mencegah tindakan-tindakan tidak manusiawi yang berdampak bagi tenaga kerja. Namun bagaimanapun, undang-undang ini masih menyimpan beberapa kelemahan terkait pengaturan TKI, seperti antara lain: ${ }^{23}$ 1) Ketidakkonsistenan dalam menerapkan aturan di mana dalam satu sisi disebutkan pelaksanaan penempatan pekerja migran terdiri atas tiga pelaksana, yaitu badan, perusahaan swasta dan mandiri. Namun, di sisi lain mengenai perjanjian penempatan pekerja migran yang merupakan salah satu dokumen wajib yang dimiliki oleh calon pekerja migran, dokumen tersebut justru hanya dimiliki oleh perusahaan swasta saja; 2) UU Nomor 18 Tahun 2017 masih menyimpan potensi konflik kelembagaan mengenai kewenangan kementerian dan institusi/badan non kementerian dalam tata kelola perlindungan tenaga kerja migran; 3) Pasal-pasal dalam UU Nomor 18 Tahun 2017 mengenai pembinaan dan pengawasan juga berpotensi sebagai

22 International Labour Organization, "Poin-Poin Penting Laporan Terbaru ILO: Tren Sosial dan Ketenagakerjaan di Indonesia 2011: Mempromosikan Pertumbuhan Lapangan Kerja di Tingkat bttps:// wmw.ilo.org/jakarta/whatwedo/eventsandmeetings/WCMS_176897/lang--en/index.btm, diakses 15 September 2020.

23 Lelisari, "Kajian Yuridis Undang-Undang Nomor 18 Tahun 2017 Tentang Perlindungan Pekerja Migran Indonesia” 13, No. 2 (2019): Hlm. 236. 
pasal karet karena tidak mengelaborasi mengenai bentuk pembinaan dan pengawasan apa yang seharusnya dilakukan untuk memastikan terselenggaranya tata kelola perlindungan tenaga kerja migran; 4) Belum adanya pasal khusus yang mengafirmasi kebutuhan khusus perlindungan tenaga kerja migran, terutama perempuan, yang bekerja di sektor domestik (asisten rumah tangga); dan 5) Peraturan mengenai bantuan hukum bagi tenaga kerja migran tidak diatur secara rinci.

Tanggungjawab negara yang paling urgent saat ini apabila melihat kelemahan UU Nomor 18 Tahun 2017 adalah perlu adanya visi dan strategi nasional dalam menjamin perlindungan TKI yang bekerja di luar negeri, seperti: 1) negara perlu mengakomodasi aturan pelaksana yang bisa dijalankan, sebab tanpa peraturan teknis tersebut, birokrasi tidak akan bisa bekerja maksimal; 2) secara kelembagaan diharuskan membentuk setiap kebijakan yang melibatkan masyarakat sipil; dan 3) akuntabilitas, ini terkait kejelasan tugas dan tanggungjawab masing-masing pemegang kepentingan termasuk dalam hal menyusun indikator keberhasilan.

Hukum internasional juga telah mengakomodasi instrumen hukum yang eksistensinya termaktub dalam International Convention on the Protection of the Rights of All Migrant Workers and Members of Their Families yang dikeluarkan Majelis Umum PBB Resolusi nomo 45/158 tanggal 18 Desember 1990. Konvensi ini mengatur bahwa tenaga kerja migran dan keluarganya memiliki hak asasi berupa: $^{24}$ 1) hak kebebasan dasar; 2) persamaan di hadapan hukum; 3) hak untuk memiliki kerahasiaan pribadi; 4) persamaan sebagai warga Negara; 5) kebebasan berkumpul/berserikat; 6) mengirimkan pendapatan; dan 7) hak untuk mendapatkan informasi.

Jadi meskipun tenaga kerja migran tersebut tidak terdokumentasi secara sah (irregular) sekalipun, mereka tidak boleh dianiaya atau diperlakukan secara tidak berperikemanusiaan. Indonesia yang merupakan anggota ILO telah meratifikasi konvensi ini melalui Undang-Undang Nomor 6 Tahun 2012 tentang Pengesahan International Convention on the Protection of the Rights of All Migrant Workers and Members of Their Families (UU Nomor 6 Tahun 2012.25 Ratifikasi tersebut berdasarkan atas Indonesia sebagai salah satu negara pengirim tenaga kerja migran terbesar di dunia namun dalam hal perlindungan dan keamanan masih tergolong rendah. ${ }^{26}$ Meskipun pada hakikatnya, konvensi

24 Adharinalti, "Perlindungan Terhadap Tenaga Kerja Indonesia Irregular Di Luar Negeri," Jurnal Rechtsvinding 1, no. 1 (2012): Hlm. 168.

25 International Convention on the Protection of the Rights of All Migrant Workers and Members of Their Families artinya Konvensi Internasional Mengenai Perlindungan Hak-Hak Seluruh Pekerja Migran dan Anggota Keluarganya.

26 Perhimpunan Indonesia Untuk Buruh Migran Berdaulat, "Siaran Pers Migrant Care Memperingati Hari Buruh Migran Sedunia" https://migrantcare.net/category/kabar/siaranpers/page/6/, diakses tanggal 15 September 2020. 
ini lebih ditujukan pada negara tujuan penempatan tenaga kerja migran agar memperoleh perlindungan, dibanding negara asal tenaga kerja migran.

Dengan Indonesia meratifikasi konvensi tersebut maka tanggungjawab negara untuk melindungi tenaga kerja migran sudah paripurna. Sebab dengan meratifikasi konvensi tersebut akan berimplikasi pada hal-hal berikut: ${ }^{27}$ 1) posisi tawar kita terhadap negara penerima paling tidak sejajar dalam negosiasi pembuatan perjanjian bilateral dengan negara tujuan penempatan. Selanjutnya kita bisa meletakkan perlindungan tenaga kerja migran dengan skema internasional sebagai bahan utama perjanjian; 2) kasus tindakan tidak berperikemanusiaan terhadap tenaga kerja yang berkondisi irregular khususnya yang dialami tenaga kerja Indonesia beserta keluarganya setidaknya akan berkurang; 3) bukti konsistensi political will pemerintah dalam mewujudkan politik hukum perlindungan tenaga kerja Indonesia di luar negeri beserta keluarganya terutama yang tidak berdokumen sah (irregular); dan 4) kerja sama dengan negara-negara dalam mengurangi tindakan tidak manusiawi akan lebih meningkat.

\section{Kesimpulan}

Tanggungjawab negara terhadap TKA seharusnya mampu mengakomodasi hak atas pekerjaan dimana dalam menjalankan tugasnya sudah ditetapkan standar kehidupan yang layak bagi warga negara. Selain itu, dalam penempatan TKA harus memiliki akses atas pekerjaan dimana TKA bebas dari HAM seperti kerja paksa, praktik perbudakan dan praktik yang disamakan dengan perbudakan, jeratan hutang, perdagangan orang, dan pernikahan paksa. Tanggungjawab negara dalam hal ini sudah akan terimplementasi dengan baik apabila pemenuhan hak-hak dasar TKA yang tertuang dalam Undang-Undang Nomor 13 Tahun 2003, yakni kesempatan dan perlakuan yang sama dalam hubungan kerja telah terpenuhi. Upaya perlindungan hukum ketengakerjaan Indonesia ditinjau dari tanggungjawab negara ini dapat dilihat pada implementasi mengenai upaya mendidik dan melatih TKI guna meningkatkan standar kompetensi yang mampu bersaing dengan TKA. Dari segi peraturan yang mengatur tujuan penggunaan TKA secara selektif dengan memprioritaskan TKI. Sehingga perlu adanya upaya dari pemerintah untuk mengintegrasikan setiap lembaga dan badan yang berkaitan dalam pengendalian dan pengawasan TKI ke dalam satu peraturan perundang-undangan yang dapat dijadikan sebagai instrumen hukum tetap mengenai pengaturan TKA. Selain itu, perlu adanya upaya dari pemerintah untuk memberikan tambahan kompetensi bagi TKI yaitu dengan melakukan program pelatihan kerja yang dilakukan secara reguler dan tidak diskriminatif, artinya tidak hanya di daerah-daerah tertentu.

27 Adharinalti, "Perlindungan Terhadap Tenaga Kerja Indonesia Irregular Di Luar Negeri," Hlm. 170. 


\section{Daftar Pustaka}

Adharinalti. "Perlindungan Terhadap Tenaga Kerja Indonesia Irregular di Luar Negeri." Jumal Rechtsvinding 1, no. 1 (2012).

Agusmidah. Dilematika Hukum Ketenagakerjaan Tinjanan Politik. Hukum. Medan: Sofmedia, 2011.

-. Hukum Ketenagakerjaan Indonesia: Dinamika Dan Kajian Teori. Bogor: Ghalia Indonesia, 2010.

Asikin, Zainal. Dasar-Dasar Hukum Perburuban. Jakarta: Raja Grafindo Persada, 2002.

Atalim, S, dan Shierly Debora. "Tinjauan Hukum Terhadap Penggunaan Tenaga Kerja Asing Di Indonesia Berdasarkan Pengaturan Yang Dibuat Oleh Presiden Nomor 20 Tahun 2018 Jo. Peraturan Menteri Ketenagakerjaan Nomor 10 Tahun 2018." Era Hukum Jurnal Imiah Ilmu Hukum 17, no. 2 (2019).

Bareta, Rizky Dian. "Politik Hukum Perlindungan Tenaga Kerja Indonesia Fase Purna Bekerja." Kanun Jurnal Ilmu Hukum 20, no. 1 (2018).

Hanifah, Ida. "Peluang Tenaga Kerja Asing Untuk Bekerja Di Indonesia Berdasarkan Rancangan Undang-Undang Cipta Kerja.” Delegalata Jurnal Ilmu Hukum 6, no. 1 (2021).

International Convention on the Protection of the Rights of All Migrant Workers and Members of Their Families Artinya Konvensi Internasional Mengenai Perlindungan Hak-Hak Seluruh Pekerja Migran dan Anggota Keluarganya.

International Labour Organization, 'Poin-Poin Penting Laporan Terbaru ILO: Tren Sosial Dan Ketenagakerjaan di Indonesia 2011: Mempromosikan Pertumbuhan Lapangan Kerja di Tingkat Provinsi', bttps:// wnw.ilo.org/jakarta/ whatwedo/eventsandmeetings/wcms_176897".

Jazuli, Ahmad. "Eksistensi Tenaga Kerja Asing di Indonesia dalam Perspektif Hukum Keimigrasian." JIKH 12, no. 1 (2018).

Undang-Undang Nomor 13 Tahun 2003 Tentang Ketenagakerjaan.

Kontan.co.id, 'Jumlah Tenaga Kerja Asing Di Indonesia 98.902, TKA China Terbesar', https:/ / nasional.kontan.co.id/news/jumlah-tenaga-kerja-asing-di indonesia-98902-tka-china-terbesar-berikut-datanya, diakses 23 Desesmber 2020.

Kuriawan, Chandra Putra. "Pemegang Hak Tenaga Kerja Asing Dalam Perspektif Hak Asasi Manusia." Jurnal JIPPK 3, no. 1 (n.d.).

Lelisari. "Kajian Yuridis Undang-Undang Nomor 18 Tahun 2017 Tentang Perlindungan Pekerja Migran Indonesia" 13, no. 2 (2019).

Mertokusumo, Sudikno. Mengenal Hukum Suatu Pengantar. Yogyakarta: Liberty, 2007.

Narsif. Hukum Diplomatik. Konsuler. Padang: Universitas Andalas, 2007. 
Nurhidayati. "Perizinan Tenaga Kerja Asing, Kebijakan Dan Implementasinya." Widya Cipta: Jurnal Sekretari Dan Manajemen 3, no. 2 (2019).

Perhimpunan Indonesia Untuk Buruh Migran Berdaulat, 'Siaran Pers Migrant Care Memperingati Hari Buruh Migran Sedunia'.

Soekanto, Soerjono, and Sri Mamudji. Penelitian Hukum Normatif - Suatu Tinjanan Singkat. Jakarta: Raja Grafindo Persada, 2004.

Soemitro, Ronny Hanitijo. Metodologi Penelitian Hukum Dan Jurimetri. Jakarta: Ghalia Indonesia, 1990.

Statistik, Badan Pusat. "Agustus 2020: Tingkat Pengangguran Terbuka (TPT) Sebesar 7,07 Persen".

Suhandi. "Pengaturan Ketenagakerjaan Terhadap Tenaga Kerja Asing Dalam Pelaksanaan Masyarakat Ekonomi ASEAN Di Indonesia." Jurnal Perspektif XXI, no. 2 (2016).

Undang-Undang Dasar Republik Indonesia Tahun 1945.

Undang-Undang Nomor 13 Tahun 2003 tentang Ketenagakerjaan.

Undang-Undang Nomor 39 Tahun 2004 tentang Penempatan dan Perlindungan Tenaga Kerja Indonesia di Luar Negeri.

Undang-Undang Nomor 6 Tahun 2012 tentang Pengesahan International Convention on the Protection of the Rights of All Migrant Workers and Members of Their Families.

Undang-Undang Nomor 18 Tahun 2017 tentang Perlindungan Pekerja Migran Indonesia.

Undang-Undang Nomor 11 Tahun 2020 tentang Cipta Kerja.

Peraturan Presiden Nomor 20 Tahun 2018 tentang Penggunaan Tenaga Kerja Asing.

Vista Puspita Sari, Risky. "Kepastian Hukum Pengaturan Penggunaan Tenaga Kerja Asing Di Indonesia.” Lentera Hukum 5, no. 3 (2018).

Wawancara dengan Juniar Herlas (Anggota DPRD Provinsi Jawa Barat) Agustus 2018.

Wawancara dengan Topik (Pekerja Proyek Kereta Cepat Rancaekek) Tanggal 16 Agustus 2020 di Transportasi Online. terms and conditions of the Creative Commons Attribution (CC BY SA) license (https://creativecommons.org/licenses/by-sa/3.0/). 